PATRICK DOYLE

CIVILISING

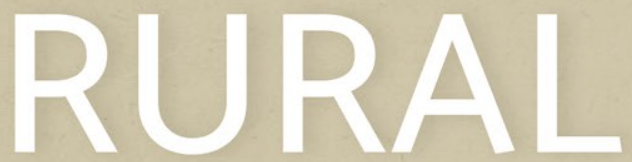

IRELAND

The co-operative movement, development and the nation-state, 1889-1939

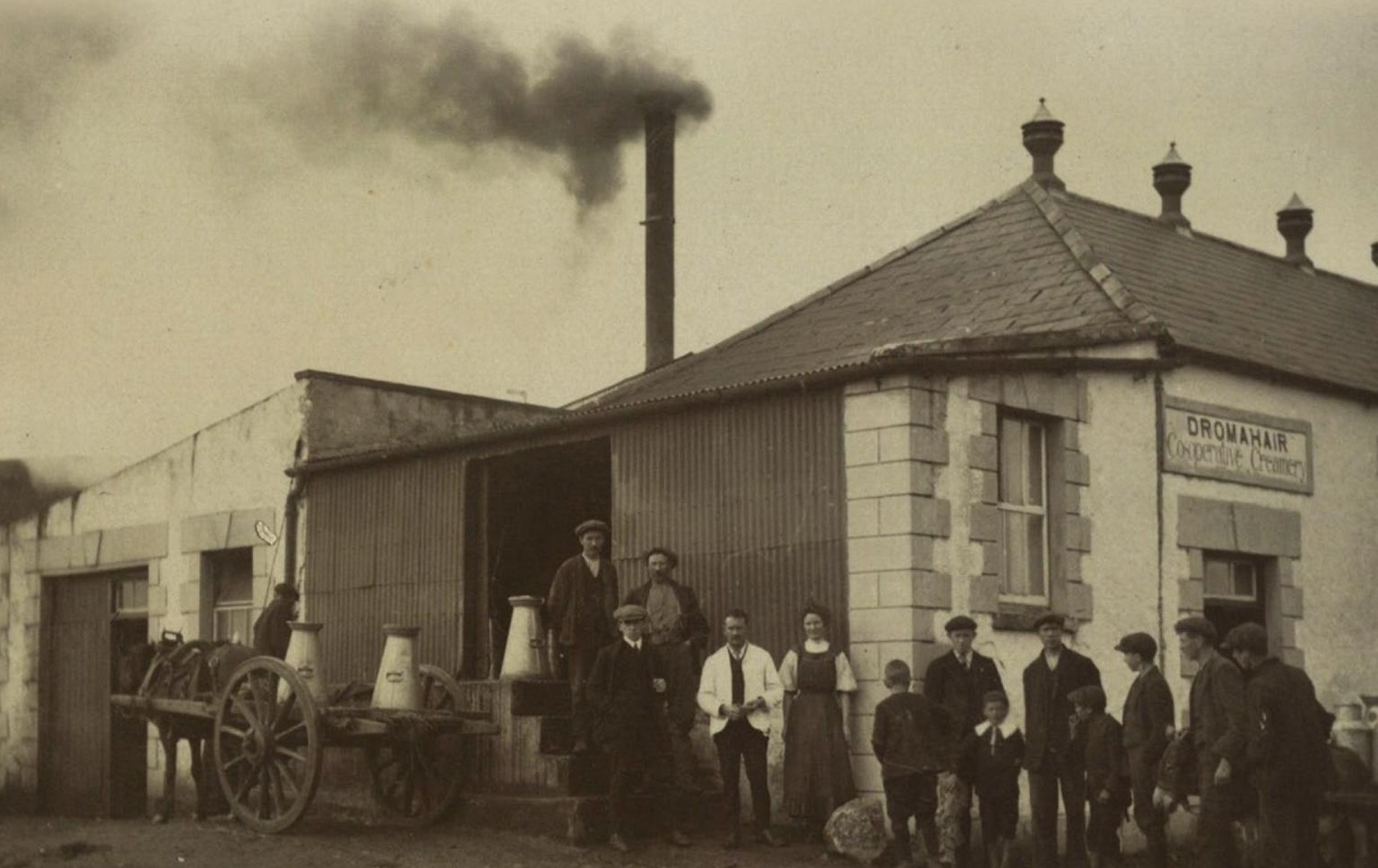




\section{Civilising rural Ireland}

\section{MANCHESTER 1824}

Manchester University Press 
Patrick Doyle - 9781526124579 Downloaded from manchesterhive.com at 04/26/2023 01:57:13PM via free access 


\title{
Civilising rural Ireland
}

\section{The co-operative movement, development and the nation-state, 1889-1939}

\author{
Patrick Doyle
}

Manchester University Press 
Copyright () Patrick Doyle 2019

The right of Patrick Doyle to be identified as the author of this work has been asserted by him in accordance with the Copyright, Designs and Patents Act 1988.

Published by Manchester University Press

Altrincham Street, Manchester M1 7JA

www.manchesteruniversitypress.co.uk

This electronic version has been made freely available under a Creative Commons (CC-BY-NC-ND) licence, thanks to the support of The University of Manchester, which permits non-commercial use, distribution and reproduction provided the author(s) and Manchester University Press are fully cited and no modifications or adaptations are made. Details of the licence can be viewed at https://creativecommons.org/licenses/by-nc-nd/4.0/

British Library Cataloguing-in-Publication Data

A catalogue record for this book is available from the British Library

ISBN 9781526124562 hardback

First published 2019

The publisher has no responsibility for the persistence or accuracy of URLs for any external or third-party internet websites referred to in this book, and does not guarantee that any content on such websites is, or will remain, accurate or appropriate.

Typeset

by Toppan Best-set Premedia Limited 